\title{
Cellular Localization of Inhibin $\alpha$-subunit, PKB/Akt and FoxO3a Proteins in the Ovaries of Minipigs
}

\author{
Chunhua MENG ${ }^{1)}$, Fangxiong SHI ${ }^{1)}$, Zhenqi ZHOU ${ }^{1)}$, Ruihua HUANG ${ }^{1}$, \\ Gentao LIU $^{2,3)}$, Gen WATANABE, ${ }^{4,5)}$ and Kazuyoshi TAYA ${ }^{4,5)}$
}

1) Laboratory of Animal Reproduction, College of Animal Science and Technology, Nanjing Agricultural University, Nanjing 210095, P. R. China, ${ }^{2}$ Maxine Dunitz Neurosurgical Institute, Cedars-Sinai Medical Center, University of California, Los Angeles, CA 90048, USA, ${ }^{3)}$ Division of Hematology/Oncology, Cedars-Sinai Medical Center/ David Geffen School of Medicine at UCLA, Los Angeles, CA 90048, USA, ${ }^{4}$ Laboratory of Veterinary Physiology, Department of Veterinary Medicine, Tokyo University of Agriculture and Technology, Tokyo 183-8509, Japan and ${ }^{5)}$ Department of Basic Veterinary Science, The United Graduate School of Veterinary Sciences, Gifu University, Gifu 501-1193, Japan

\begin{abstract}
Experiments were conducted to examine the cellular localization of inhibin $\alpha$-subunit, protein kinase $\mathrm{B}$ (PKB/Akt), and FoxO3a proteins in the ovaries of minipigs, Chinese Xiang pigs, by immunohistochemistry. The results indicated that inhibin $\alpha$-subunits were localized in the granulosa cells of follicles at all stages but were not localized in corpora lutea. PKB was localized in the granulosa cells of primordial follicles and in the basal layers of the granulosa cells of preantral and antral follicles, but were not localized in atretic follicles and corpora lutea. FoxO3a was localized in the granulosa cells of follicles at all stages and was extensively localized in the cytoplasma of the luteinized granulosa cells of corpora lutea. Together, the stage- and cell-specific expression patterns of inhibin $\alpha$-subunit, FoxO3a, and PKB suggest that these proteins might play potential roles in follicular development, atresia, and luteinization in the minipig.
\end{abstract}

Key words: FoxO3a, Inhibin, Minipig, Ovary, Protein kinase B (PKB)

(J. Reprod. Dev. 53: 229-236, 2007)

$\mathbf{X}$ iang pigs are a world famous breed of miniature pigs mainly distributed in the Guizhou and Guangxi provinces of China. The miniature pig has become a perfect animal model for biomedical research because of its dwarfism, purity gene type, physiological characteristics similar to human beings and lack of inbreeding degradation [1-5]. However, knowledge of the reproductive physiology of this species is extremely limited.

Accepted for publication: October 14, 2006

Published online: November 29, 2006

Correspondence: F. Shi (e-mail: fxshi@njau.edu.cn)
Ovarian inhibin is a key hormone that regulates the development, selection, and dominance of follicles through suppression of pituitary folliclestimulating hormone (FSH) secretion [6-8]. Active and passive immunization against inhibin is a good way to induce superovulation in many animals through an increase in the concentration of FSH [816]. Ovarian inhibin is composed of disulfidebonded $\alpha$ - and $\beta$-subunits. Combination of the $\alpha$ subunit with either the $\beta \mathrm{A}$ or $\beta \mathrm{B}$ subunit $(\alpha / \beta \mathrm{A}$ or $\alpha / \beta \mathrm{B})$ forms an inhibin molecule. Although a limited number of studies have described the immunohistochemical localization of inhibin in 
pigs $[17,18]$, there is still no data on their immunohistochemical localization in the ovaries of minipigs.

Protein kinase B (PKB, also called Akt) is a serine/threonine protein kinase that functions as a critical regulator of nutrient metabolism, cell growth, proliferation, and apoptosis [19, 20]. PKB can be phosphorylated and activated by FSH in rat granulosa cells via the protein kinase-A independent pathway [21]. Although there are several reports about localization of PKB in different tissues and cells [22,23] and immunoblot analysis of PKB in ovaries [24], the immunolocalization of PKB in the ovary has yet to be reported.

Forkhead members of the $\mathrm{O}$ class (FoxO) are transcription factors that play a critical role in a growing number of physiological processes, including apoptosis, cell cycle progression, and insulin signaling $[25,26]$. Four FOXO members, FoxO1 (FKHR), FoxO3a (FKHRL1), FoxO4 (AFX), and FoxO6, are mostly studied in vertebrates [2729]. Previous studies indicate that FoxO1 is expressed in a regulated, cell-specific manner during ovarian follicular development, atresia, and luteinization [26, 30, 31]. Recent findings indicate that at the earliest stages of follicular growth, FoxO3a functions as a suppressor of follicular activation and eventually causes signs of premature aging [32]. Therefore, it is important to examine the localization of FoxO3a in the ovaries.

Follicular development, atresia, and luteinization are elaborately regulated by endocrine, paracrine and autocrine factors. Recently, the PKB/Akt pathway has attracted remarkably attention from scientists. Therefore, the aim of the present study was to examine the cellular localization of inhibin $\alpha$-subunit, PKB/Akt and FoxO3a proteins in the ovaries of Chinese Xiang pigs using immunohistochemistry.

\section{Materials and Methods}

\section{Animals and sample collection}

Eight Xiang pigs were obtained from the Jiangpu farm of Nanjing Agricultural University, Nanjing, P. R. China. The minipigs used in this experiment had body weights of $20-40 \mathrm{~kg}$ and were 5 -8 months of age. The animals were kept indoors and were provided with commercial foods three times daily and tap water ad libitum. The experimental protocol was approved in accordance with the Guide for the Care and Use of Laboratory Animals prepared by the Institutional Animal Care and Use Committee of Nanjing Agricultural University.

In order to examine the cellular localization of inhibin $\alpha$-subunit, PKB/Akt and FoxO3a proteins in the ovaries of Chinese Xiang pigs, the ovaries were immediately removed from anesthetized Xiang pigs and fixed in $4 \%$ paraformaldehyde at room temperature overnight. After transferring through a graded serries of alcohol and xylene, the ovaries were embedded in paraffin and sectioned at $8 \mu \mathrm{m}$ thickness. The ovarian sections were mounted on slides and processed for immunohistochemical analysis.

\section{Reagents}

The inhibin $\alpha$-subunit antiserum was obtained from a rabbit immunized against [Tyr30] porcine inhibin $\alpha$-chain (1-30)- $\mathrm{NH}_{2}$ conjugated to rabbit serum albumin [33]. This conjugate was kindly provided by Dr. N. Ling (Neuroendocrine Biosciences, La Jolla, CA, USA). Antibodies for FoxO3a (Cat. No. 06-951, Lot 27567) [34] and PKB/ Akt (Cat. No. 9472, Lot 1) [35] were obtained from Cell Signaling Technology (Beverly, MA, USA). An $\mathrm{ABC}$ Kit was obtained from BioGenex (San Ramon, CA, USA) and 3,3'-diaminobenzidine tetrachloride (DAB) was purchased from Sigma Chemical (St. Louis, MO, USA). All other chemicals were obtained commercially and were of reagent grade.

\section{Immunohistochemistry}

Immunohistochemical analysis was conducted in a manner similar to the methods used in our previous reports [10, 25, 36]. Briefly, sections were incubated overnight at room temperature with a polyclonal rabbit immunoaffinity-purified antiserum directed against the inhibin $\alpha$-subunit (1:2000), FoxO3a (1:100) and PKB proteins (1:100). The specific protein immunoreactivity was visualized with an $\mathrm{ABC}$ Kit Elite and $0.05 \% \mathrm{DAB}$ in $10 \mathrm{mM}$ PBS-buffered saline containing $0.01 \% \mathrm{H}_{2} \mathrm{O}_{2}$ for $5 \mathrm{~min}$. Specificity of the antibody was examined using normal rabbit serum instead of primary antibody. In order to identify structural components and cell types within the ovaries, the sections were counterstained with hematoxylin and mounted with coverslips. Relative levels of immunostaining between animals and cell types 

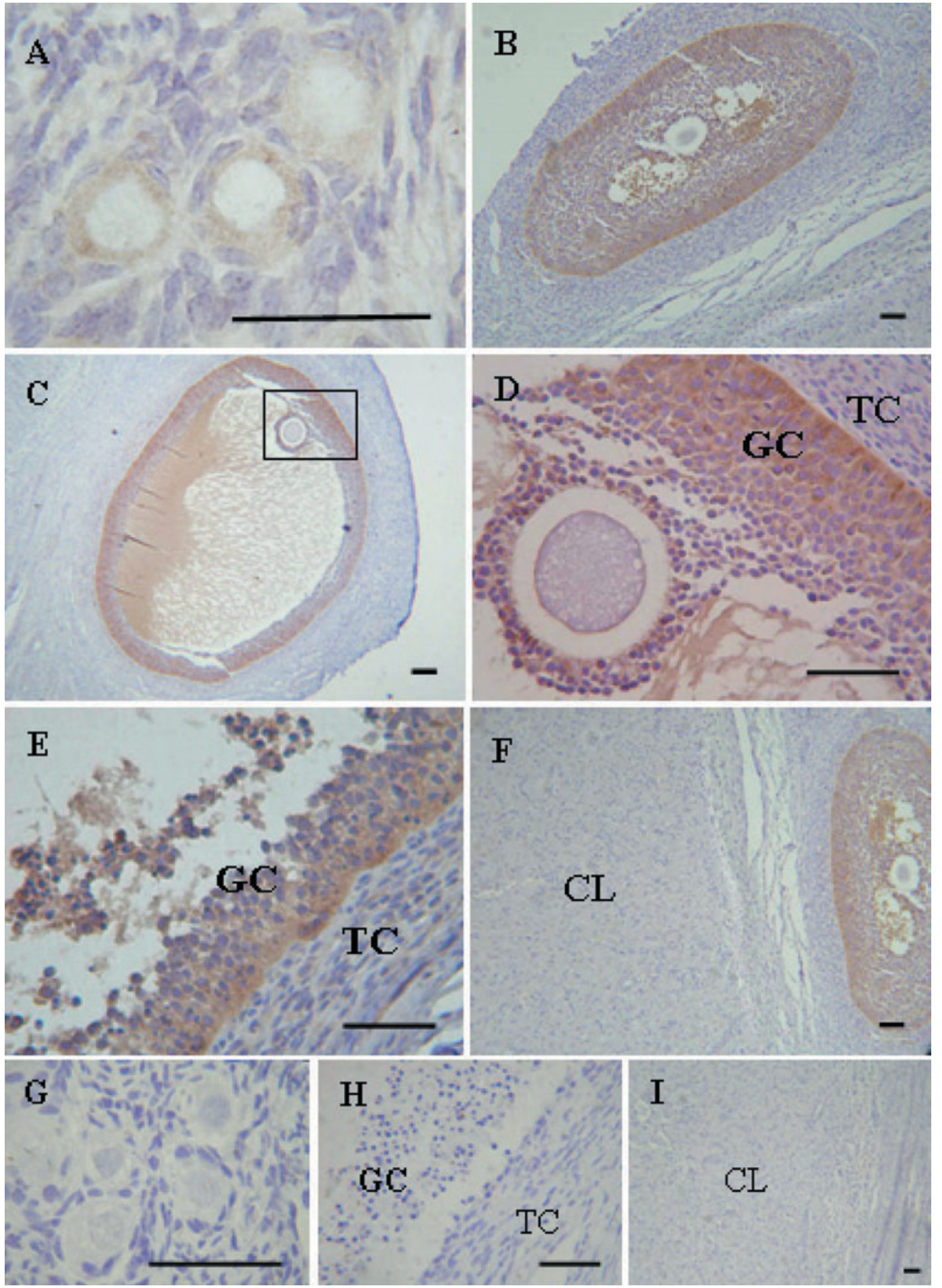

Fig. 1. Cellular localization of inhibin $\alpha$-subunit during follicular development in the ovaries of Xiang pigs. Positive immunostaining for inhibin $\alpha$-subunit is indicated by a brown reaction product. Note that inhibin immunoreactivity was detected in the granulosa cells (GCs) of primordial (A), preantral (B), antral (C, D) and antretic follicles (E) and that no significant inhibin staining was detected in theca (TC), stromal and corpora lutea cells (CL, F). In control sections, no significant immunoreactivity was observed when normal rabbit serum was used instead of primary antibody $(\mathrm{G}, \mathrm{H}, \mathrm{I})$. Bar=50 $\mu \mathrm{m}$. 

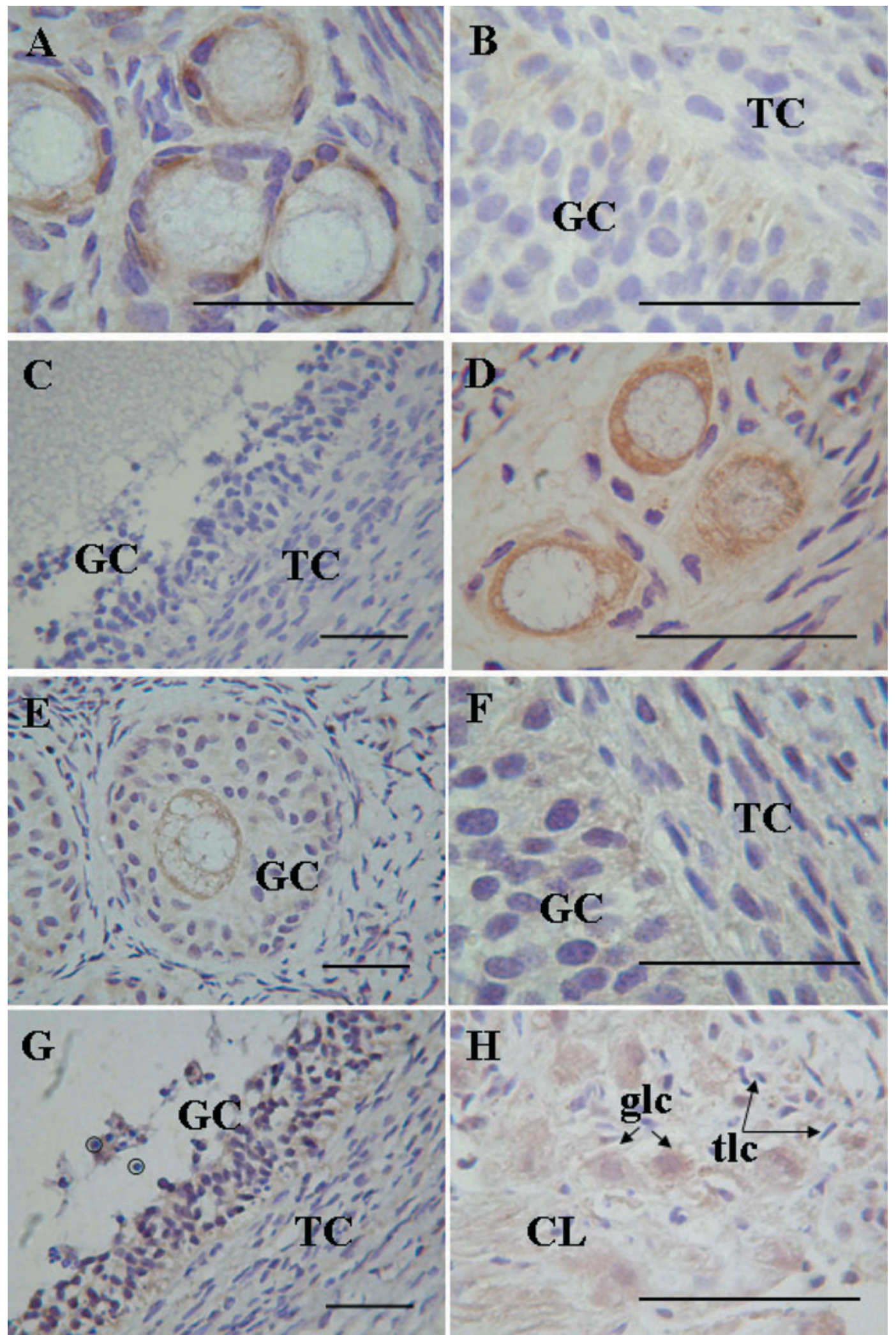
were evaluated by three independent observers, and this was repeated at least four times. The results described herein represent consistently observed patterns of immunohistochemistry.

\section{Results}

\section{Localization of inhibin $\alpha$-subunit}

Immunohistochemical analysis of the ovarian tissues revealed that expression of the inhibin $\alpha$ subunit was found in the granulosa cell (GC) layer of primordial (Fig. 1A), preantral (Fig. 1B), antral (Fig. 1C, 1D), and atretic (Fig. 1E) follicles, but no expression was found in theca cells (TC) and stromal cells. Inhibin immunoreactivity was absent from corpora lutea (Fig. 1F) and was faint in the GCs of primordial follicles. The stained intensity of inhibin immunoreactivity increased in the GCs of preantral and antral follicles and decreased when follicles became atretic. In addition, there was no inhibin immunoreactivity in ovarian vascular endothelial cells (data not shown).

\section{Localization of $P K B / A k t$}

PKB immunoreactivity was found in flat GCs of primordial follicles (Fig. 2A). Interestingly, it was mainly localized in the basal layers of the GCs in antral follicles (Fig. 2B). Immunoreactivity of PKB was also localized in ovarian vascular endothelial cells (data not shown). However, PKB protein was not detected in atretic follicles (Fig. 2C) and corpora lutea (data not shown).

\section{Localization of FoxO3a}

FoxO3a immunoreactivity was localized in the ovaries throughout every stage of follicular development, atresia, and luteinization. It was mainly localized in the oocyte cytoplasm and granulosa cells of primary (Fig. 2D), preantral (Fig. 2E), antral (Fig. 2F), and atretic (Fig. 2G) follicles as well as ovarian vascular endothelial cells (data not shown). In corpora lutea, FoxO3a immunoreactivity was localized specifically in the cytoplasm of luteinized granulosa cells (glc) but not in thecal luteal cells (tlc) (Fig. 2H). No significant localization of FoxO3a was observed in the pycnotic granulosa cells (shown in circles in Fig. 2G) of atretic follicles. These results demonstrate the obligatory function of FoxO3a for the ovaries during the estrous cycle.

\section{Discussion}

The findings of the present study clearly demonstrate the cell-specific localization of inhibin $\alpha$-subunits, PKB, and FoxO3a in the ovaries of Chinese Xiang pigs using immunohistochemical analysis.

Our results from immunohistochemical staining of inhibin $\alpha$-subunits in the granulosa cells of healthy follicles from Xiang pigs are similar to those obtained in other reports for other animals [10]. However, the results of Kishi et al. (2002) demonstrated that inhibin $\alpha$-subunit is also present in interstitial cells on the first 3 days of the estrous cycle and newly formed luteal cells in the golden hamster [37]. The decrease in stain intensity of the atretic follicles in Xiang pigs is also consistent with observations in other animals $[7,10,38]$.

The Akt/PKB signaling pathway is now recognized as one of the most critical pathways regulating cell survival [39-43]. In the present study, it was interesting that PKB was localized specifically at the basal layers of the granulosa cells in antral follicles, which implies that PKB is involved in connection and interaction between theca and granulosa cells. It is well known that synthesis of estradiol is a two-cell process. Whether PKB is involved in this process or not needs further clarification. Ovarian localization of PKB was not limited to follicles, but was also found in blood vascular epithelia. This is in agreement

Fig. 2. Cellular localization of $\mathrm{PKB} / \mathrm{Akt}$ and FoxO3a during follicular development in the ovaries of Xiang pigs. PKB immunoreactivity was detected in the flat granulosa cells (GCs) of primordial follicles (A) and basal layers of the GCs in antral follicles (B). No significant immunoreactivity of PKB was detected in atretic follicles (C) and corpora lutea (data not shown). FoxO3a immunoreactivity was mainly detected in GCs of primary (D), preantral (E), antral (F), and atretic (G) follicles and was extensive in the cytoplasma of lutealized granulosa cells (glc) but not in the thecal luteal cells (tlc) of corpora lutea $(\mathrm{H})$. No significant localization of FoxO3a was detected in the pycnotic granulosa cells (shown in circles in $\mathrm{G})$ of atretic follicles. In control sections, no significant immunoreactivity was observed when normal rabbit serum was used instead of primary antibody (same as in Fig. 1). Bar=50 $\mu \mathrm{m}$. 
with the findings of Johnson et al. (2001), who showed that Akt plays a more ubiquitous role in the signal pathways of multiple origins [43].

The fact that FoxO3a was localized in follicles and corpora lutea throughout the ovarian cycle in the Chinese Xiang pigs indicates that FoxO3a may play potential roles in the ovary. In addition, there was no PKB immnuoreactivity in atretic follicles and corpora lutea when FoxO3a immnuoreactivity was localized in the granulosa cells of atretic follicles and in the plasma of granulosa luteal cells in corpora lutea. This indicates that FoxO3a may not only be regulated by PKB, but may also be regulated by other kinases [44, 45].

In conclusion, the fact that cell-specific localization of PKB/Akt and FoxO3a was found in the ovaries of Chinese Xiang pigs indicates that the pathway of PKB and FoxO3a is involved in follicular development, atresia, and luteinization, and some colocalization of inhibin $\alpha$-subunits,
PKB/Akt, FoxO3a implies that the pathway of $\mathrm{PKB} / \mathrm{Akt}$ and FoxO3a is involved in the secretion of inhibin, therefore regulating ovarian function in the minipig.

\section{Acknowledgements}

This study was supported in part by the National Nature Science Foundation of China (No. 30571335), a Grant-in-Aid for Scientific Research (The $21^{\text {st }}$ Century Center of Excellence Program, E1) from the Ministry of Education, Culture, Sports, Science and Technology of Japan, and a Grand-inAid for Scientific Research, B-18310044 from the Japan Society for the Promotion of Science. We thank Mr. Jinbiao Luo, a master student at Nanjing Agricultural University, for his technical assistance. We thank the Jiangpu Farm in Nanjing, China, for supplying the animals used in this experiment.

\section{References}

1. Gan S, Ji L, Wei Y, Chen Y, Feng J, Dong F. Study on Xiang pigs in GuiZhou province as experimental animals. Shanghai Laboratory Animal Science 1989; 9: 227-229.

2. Wang $X$, Ou J, Huang L, Nishihara M, Li J, Manabe N, Zhang Y. Genetic characteristics of inbred Wuzhishan miniature pigs, a native chinese breed. J Reprod Dev 2006; 52: 639-643.

3. Grabbe S, Fishbein JM, Sachs DH, Flotte TJ, Granstein RD. Characterization of cutaneous antigen presentation in partially inbred miniature swine. Exp Dermatol 1994; 3: 276-282.

4. Sachs DH. The pig as a potential xenograft donor. Vet Immunol Immunopathol 1994; 43: 185-191.

5. Chao SH, Chieng PU, Lee PH, Chu SH, Chen KM. Octreotide effects on pancreatic graft pancreatitis in inbred pigs. Transplant Proc 1996; 28: 1799-1801.

6. Molskness TA, Woodruff TK, Hess DL, Dahl KD, Stouffer RL. Recombinant human inhibin-A administered early in the menstrual cycle alters concurrent pituitary and follicular, plus subsequent luteal, function in rhesus monkeys. J Clin Endocrinol Metab 1996; 81: 4002-4006.

7. Shi F, Ozawa M, Komura H, Yang $\mathbf{P}$, Trewin AL, Hutz RJ, Watanabe G, Taya K. Secretion of ovarian inhibin and its physiologic roles in the regulation of follicle-stimulating hormone secretion during the estrous cycle of the female guinea pig. Biol Reprod 1999; 60: 78-84.

8. Kishi H, Okada T, Otsuka M, Watanabe G, Taya K,
Sasamoto S. Induction of superovulation by immunoneutralization of endogenous inhibin through the increase in the secretion of folliclestimulating hormone in the cyclic golden hamster. $J$ Endocrinol 1996; 151: 65-75.

9. Nambo $\mathbf{~ , ~ K a n e k o ~ H , ~ N a g a t a ~ S , ~ O i k a w a ~} M$, Yoshihara T, Nagamine N, Watanabe G Taya K. Effect of passive immunization against inhibin on FSH secretion, folliculogenesis and ovulation rate during the follicular phase of the estrous cycle in mares. Theriogenology 1998; 50: 545-557.

10. Shi F, Mochida K, Suzuki O, Matsuda J, Ogura A, Ozawa M, Watanabe G, Suzuki AK, Taya K. Ovarian localization of immunoglobulin $G$ and inhibin $\alpha$-subunit in guinea pigs after passive immunization against the inhibin $\alpha$-subunit. $J$ Reprod Dev 2000; 46: 293-299.

11. Wang H, Herath CB, Xia G, Watanabe G, Taya K. Superovulation, fertilization and in vitro embryo development in mice after administration of an inhibin- neutralizing antiserum. Reproduction 2001; 122: 809-816.

12. Ishigame $H$, Medan MS, Watanabe G, Shi Z, Kishi H, Arai KY, Taya K. A new alternative method for superovulation using passive immunization against inhibin in adult rats. Biol Reprod 2004; 71: 236-243.

13. Ishigame $\mathbf{H}$, Medan MS, Wang $H$, Watanabe $G$, Kishi H, Arai KY, Taya K. Induction of superovulation by immunoneutralization of endogenous inhibin in immature rats. J Reprod Dev 
2005; 51: 559-566.

14. Takedomi T, Kishi H, Medan MS, Aoyagi $Y$, Konishi M, Itoh T, Yazawa S, Watanabe G, Taya K. Active immunization against inhibin improves superovulatory response to exogenous FSH in cattle. J Reprod Dev 2005; 51: 341-346.

15. Medan MS, Takedom T, Aoyagi Y, Konishi M, Yazawa S, Watanabe G, Taya K. The effect of active immunization against inhibin on gonadotropin secretions and follicular dynamics during the estrous cycle in cows. J Reprod Dev 2006; 52: 107-113.

16. Sasaki K, Medan MS, Watanabe G, Sharawy S, Taya K. Immunization of goats against inhibin increased follicular development and ovulation rate. J Reprod Dev 2006; 52: 543-550.

17. Rokukawa S, Inoue K, Miyamoto K, Kurosumi K, Igarashi M. Immunohisto-chemical localization of inhibin in porcine and bovine ovaries. Arch Histol Jpn 1986; 49: 603-611.

18. Weng $Q$, Medan MS, Watanabe G, Tsubota T, Tanioka Y, Taya K. Immunolocalization of steroidogenic enzymes P450scc, 3betaHSD, P450c17, and P450arom in Gottingen miniature pig testes. J Reprod Dev 2005; 51: 299-304.

19. Birkenkamp KU, Coffer PJ. Regulation of cell survival and proliferation by the FOXO (Forkhead box, class O) subfamily of Forkhead transcription factors. Biochem Soc Trans 2003; 31: 292-297.

20. Song G, Ouyang G, Bao S. The activation of Akt/ PKB signaling pathway and cell survival. J Cell Mol Med 2005; 9: 59-71.

21. Gonzalez-Robayna IJ, Falender AE, Ochsner S, Firestone GL, Richards JS. Follicle-Stimulating hormone (FSH) stimulates phosphorylation and activation of protein kinase $\mathrm{B}$ (PKB/Akt) and serum and glucocorticoid-lnduced kinase (Sgk): evidence for A kinase-independent signaling by FSH in granulosa cells. Mol Endocrinol 2000; 14: 1283-1300.

22. Camper-Kirby D, Welch S, Walker A, Shiraishi I, Setchell KD, Schaefer E, Kajstura J, Anversa P, Sussman MA. Myocardial Akt activation and gender: increased nuclear activity in females versus males. Circ Res 2001; 88: 1020-1027.

23. Syed NA, Horner KN, Misra V, Khandelwal RL. Different cellular localization, translocation, and insulin-induced phosphorylation of PKBalpha in HepG2 cells and hepatocytes. J Cell Biochem 2002; 86: 118-127.

24. Evans AC, Martin F. Kinase pathways in dominant and subordinate ovarian follicles during the first wave of follicular development in sheep. Anim Reprod Sci 2000; 64: 221-231.

25. Nakae J, Biggs WH 3rd, Kitamura T, Cavenee WK, Wright CV, Arden KC, Accili D. Regulation of insulin action and pancreatic beta-cell function by mutated alleles of the gene encoding forkhead transcription factor Foxo1. Nat Genet 2002; 32: 245-
253.

26. Li X, Jiang Y, Wang Z, Liu GT, Hutz RJ, Liu WB, Shi F. Regulation of FoxO1 transcription factor by nitric oxide and cyclic GMP in cultured rat granulosa cells. Zool Sci 2005; 22: 1339-1346.

27. Arden KC, Biggs WH 3rd. Regulation of the FoxO family of transcription factors by phosphatidylinositol-3 kinase-activated signaling. Arch Biochem Biophys 2002; 403: 292-298.

28. Jacobs FMJ, Heide LP, Patrick JECW, Burbach JPH, Hoekman MFM, Smidt MP. FoxO6, a novel member of the FoxO class of transcription factors with distinct shuttling dynamics. J Biol Chem 2003; 278: 35959-35967.

29. Hoekman MF, Jacobs FM, Smidt MP, Burbach JP. Spatial and temporal expression of FoxO transcription factors in the developing and adult murine brain. Gene Expression Patterns 2006; 6: 134140.

30. Richards JS, Sharma SC, Falender AE, Lo YH. Expression of FKHR, FKHRL1, and AFX genes in the rodent ovary: evidence for regulation by IGF-I, estrogen, and the gonadotropins. Mol Endocrinol 2002; 16: 580-599.

31. Shi F, LaPolt PS. Relationship between FoxO1 protein levels and follicular development, atresia, and luteinization in the rat ovary. J Endocrinol 2003; 179: 195-203.

32. Castrillon DH, Miao L, Kollipara R, James WH, Ronald AD. Suppression of ovarian follicle activation in mice by the transcription factor Foxo3a. Science 2003; 301: 215-218.

33. Weng $Q$, Medan MS, Xu M, Tsubota T, Watanabe G, Taya K. Seasonal changes in immunolocalization of inhibin/activin subunits and testicular activity in wild male Raccoon dogs (Nyctereutes procyonoides). J Reprod Dev 2006; 52: 503-510.

34. Muraoka RS, Dumont N, Ritter CA, Dugger TC, Brantley DM, Chen J, Easterly E, Roebuck LR, Ryan S, Gotwals PJ, Koteliansky V, Arteaga CL. Blockade of TGF-beta inhibits mammary tumor cell viability, migration, and metastases. J Clin Invest 2002; 109: 1551-1559.

35. Kotani K, Ogawa W, Matsumoto M, Kitamura T, Sakaue H, Hino Y, Miyake K, Sano W, Akimoto K, Ohno S, Kasuga M. Requirement for activation of the seriene-threonine kinase Akt (protein kinase B) in insulin stimulation of protein synthesis but not of glucose transport. Mol Cell Biol 1998; 18: 3708-3717.

36. Zhou Z, Wang T, Pan L, Huang R, Shi F. FoxO4 is the main forkhead transcriptional factor expressed in the gastrointestinal tracts of pigs. J ZheJiang Uni Sci 2007; 8: 39-44.

37. Kishi H, Ohshima K, Itoh M, Tsukada J, Arai KY, Nakano S, Watanabe G, Taya K. Changes in expression of inhibin subunits in the cyclic golden hamster (Mesocricetus auratus) and the regulation of 
inhibin $\alpha$ subunit production by luteinizing hormone. Zool Sci 2002; 19: 225-232.

38. Guthrie HD, Ireland JLH, Good TEM, Ireland JJ. Expression of different molecular mass forms of inhibin in atretic and nonatretic follicles during the early luteal phase and altrenogest-synchronized follicular phase in pigs. Bio Reprod 1997; 56: 870-877.

39. Bao SD, Ouyang GL, Bai XF, Huang Z, Ma C, Liu M, Shao R, Anderson RM, Rich JN, Wang XF. Periostin potently promotes metastatic growth of colon cancer by augmenting cell survival via the Akt/PKB pathway. Cancer Cell 2004; 5: 329-339.

40. Shi Q, Bao SD, Maxwell JA, Reese1 ED, Friedman1 HF, Bigner DD, Wang XF, Rich1 JN. Secreted protein acidic, rich in cysteine (SPARC) mediates cellular survival of gliomas through AKT activation. J Biol Chem 2004; 279: 52200-52209.

41. Gupta D, Syed NA, Roesler WJ, Khandelwal RL. Effect of overexpression and nuclear translocation of constitutively active PKB-alpha on cellular survival and proliferation in HepG2 cells. J Cell Biochem 2004; 93: 513.

42. Wendel HG, De Stanchina E, Fridman JS, Malina A, Ray S, Kogan S, Cordon CC, Pelletier J, Lowe SW. Survival signalling by Akt and eIF4E in oncogenesis and cancer therapy. Nature 2004; 428: 332-337.

43. Johnson AL, Bridgham JT, Swenson JA. Activation of the Akt/Protein kinase B signaling pathway is associated with granulosa cell survival. Biol Reprod 2001; 64: 1566-1574.

44. Heide VDL, Hoekman MF, Smidt MP. The ins and outs of FoxO shuttling: mechanisms of FoxO translocation and transcriptional regulation. Biochem J 2004; 380: 297-309.

45. Morris BJ. A forkhead in the road to longevity: the molecular basis of lifespan becomes clearer. J Hypertens 2005; 23: 1285-1309. 